\title{
Parent Differentiation of Self: The Mother of Adolescent Sexual Offenders
}

\author{
Nila Anggreiny ${ }^{1 *}$, Septi Mayang Sarry ${ }^{1}$, Mafaza $^{1}$, Agung Rachmadi $^{1}$ \\ ${ }^{1}$ Psychology Department, Andalas University, Padang, Indonesia \\ "Corresponding author. Email: nilaanggreiny@gmail.com
}

\begin{abstract}
The number of sexually abusive cases has over the years increased tremendously, with adults as well as adolescents being the perpetrators of this inhumane act. Several factors are known to influence the emergence of weird and kinky behaviors in people, one of which is family. One essential concept of family systems theory is the ability to differentiate the individual capacity each member in order to regulate their emotional reactions and balance between intimacy and autonomy in relationships. The aim of this study is to describe parental role in differentiating their children capability, especially mothers of sexual offenders. This study made use of the qualitative method with phenomenological approach. The data were collected using an indepth interview, while a purposive sampling technique was used to select the subjects. The results showed that the subjects were so full of their personality and showed no emotional imbalance when a problem related to other people occurs. However, the subjects showed excessive emotional reactions and difficulties in controlling emotions. Such emotional reactions eventually lead to an imbalance of self-differentiation and difficulties in responding to problems appropriately. These results suggest that emotional reactivity is the dominant factor of parent's inability to differentiate their wards attitude. The findings could be used for family-based therapy, specifically for juvenile sexual offender.
\end{abstract}

\section{Keywords: Differentiation of self, juvenile sex offender, mother}

\section{INTRODUCTION}

Every year, there is an increase in the numerous cases of child molestation. These molestations are usually in the form of physical assault, maltreatment, sexual abuse, bullying and lots more (Finkelhor, Turner, Hamby, \& Ormrod, 2011). One of the most common forms of victimization toward children is sexual abuse. Sexual abuse against children and adolescents is not only carried out by external parties, but also by these victims' family memebers and loved ones (Kring, Johnson, Davison, \& Neale, 2014). Friendman, Marshal, Guadamuz, Wei, Wong, Saewyc, \& Stall (2011) characterized children who are sexual abused as those that are forcefully engaged into participating in sexual intercourse.

Adults are not the only sex offenders, as adolescents have joined in carrying out this ungodly act. According to a juridical court, a juvenile sexual offender is a person between the ages of 15-16 years who indulges in rape, penetration, exhibitionism, intercourse, oral and genital contact, fondling and other sexual offenses against the opposite or same sex (Prisco, 2015). This can be seen from the data gathered by the National Commission for Child Protection (KPAI) which stated that a total of 1,519 children were sexual abused from 2011-2016, with about 561 children in 2014 (Bank Data
KPAI, 2016). There are several characteristics of adolescent sex offenders such as: (a). they are usually between the ages of 13-17 years, (b). find it difficult to control their emotions, (c). More than $80 \%$ are diagnosed with psychiatric disorders, (d). 30-60\% experience learning disorders, (e). 20-50\% have experienced physical violence, (f). $40-80 \%$ have been sexually abused(www.csom.org/pubs/).

There are numerous factors that lead adolescents into becoming sex offenders. One of such factors is parents parenting style. This tends to influence the formation of behavior in children. Research has it that a good number of Juvenile perpetrators of this act, is as a result of poor parental upbringing. If the adolescent abuses a peer mate, there is every possibility that he lacked parental upbringing. One the other hand, if a younger child is abused, then the culprit experienced dominant parenting style (Marshal, 2010). The lack of attachment between children and parents, results in rapid sexual development, exposure to pornography, drugs, and alcohol. Exposure to media pornographic materials increases the risk of brain damage, which can lead to addiction, high sexual desire, and sexual dysfunctioning problems (Anisah, 2016). In fact, children who are exposed to pornography at an early age will be more at risk of becoming perpetrators of 
sexual violence (Naidoo, Vishanthie, \& Sewpaul, 2014). According to KPAI (2017), the increase in violence cases against children have become worrisome to the society, with high rate of sexual violence cases.

In addition to their exposure to pornographic materials at a very young age (Brown \& Burton, 2010), other factors that can influence their indulgent into sexual violence, include having experienced sexual abuse, history of criminality in the family, growing up in unconducive environment, living with a singleparent, academic failure and previous sexual intercourse and lots more. In general, family dysfunction is the main feature that is always found in a juvenile who committed the sexual violence. Although this act was committed by the adolescent, the family, especially parents have a significant role to play in shaping a child's behavior (Margari, et al, 2015)

Parental role determines a child's current condition, including self-control and the development of positive behavior in the future. As stated by Franklin and Bouffard (2012), the level of self-control can explain the reasons behind criminal acts, especially sexual violence. The lack of parental roles in the family is one major factor that leads to the emergence of this behavior (Anggreiny, Sarry \& Azziza, 2016). Carrying out parental roles on adolescents involved in sexual violence is usually a tough challenge for parents. Moreover, the offenders are adolescence experiencing physical, cognitive, emotional, and social changes, hence, making it tasking for parents to get hold of them (Papalia, Olds, and Feldman, 2009). Therefore, to address these challenges, parents, especially mothers of the juvenile sex offender required to have selfcompetence. Clinical research also found the evolution of negative and antisocial behaviors as a result of poor communication in the family (Hall, 2016).

There are several functions that must be carried out in the family, such as: education, socialization, protection, love, religion, economy, recreation, biology, and affection (Clayton, in Suratno, 2014). The distribution of roles in the family causes a teenager to emotionally feel closer to their mother, this is because mothers tend to interact, provide and comfort their children more than fathers' $c$ (Eliasa, 2011). However, based on a research on adolescent sex offenders, mothers are tagged inadequate with the inability to make decisions for the family (Anggreiny, 2016). This explains why the role of a mother in the family is very influential on the behavior of children in the future.

Many of the above studies about families show their influence on the formation of children's behavior. One of the concepts announced by Bowen in the family system theory is the Differentiation of self. According to Bowen (in Hall, 2013) differentiation of self is defined as the capacity of a system to manage emotional reaction, act thoughtfully under stress, and allow intimacy and autonomy in relationships.
Differentiation of self includes thinking, feeling and emotional behavior. Parents with higher levels of selfdifferentiation are less emotionally reactive, maintain a clearer sense of self attributes, and are more capable of handling intimate and autonomous relationships. In contrast, less differentiated parents are less able to regulate their emotional responses, maintain a solid sense of self discipline, are more emotionally reactive, and less comfortable with intimacy and or autonomy in family relationships. This study aims to describe the differentiation of self among mothers of juvenile sexual offenders.

\section{METHOD}

This research uses qualitative research design and phenomenology methodology in of the formulation and interpretation of Parental self-differentiation: The mother of Adolescent Sexual Offenders. This research used one data source that is mothers as participants. Sample participants in this research are mothers of juvenile sexual offenders. In-depth and unstructured qualitative interviews were used in obtaining data used in this research. The researchers also conducted informal observation by observing the participants during the interview session and in their daily life.

The data collected by using in-depth interview resulted to 5 participants, who happened to be mothers of juvenile sexual offenders. Analysis was carried out in the following few steps. Firstly, these data was organized and given a systematic code. After that, researchers carried out initial analysis with the obtained data to extract the keyword and code. Next the researcher grouped these keywords into themes and tried locating the right patterns and relationship between the themes. The last step is research finding which are reviewed based on theories.

\section{RESULT AND DISCUSSION}

The findings, in general, shows that mothers of juvenile sexual offenders lacked self-differentiation. This is indicated by their imbalance emotional and intellectual functioning and the difficulty in thinking objectively. In addition, the balance between intimacy and autonomy in interpersonal relationships also seems inadequate. Almost all subjects have a dominant basic self with only one showing a higher degree pseudo self. However, the balance still cannot be obtained because the relationship between mother, children, and the other family members were not close enough. These results are in accordance with the concept developed by Bowen (as cited in Hall, 2013) which describes selfdifferentiation as a balance between two main things, namely emotional drive and togetherness.

The imbalance between emotional and intellectual functions is shown by excessive emotional reactivity (Biadsy-Ashksar \& Peleg, 2013). Emotional reactivity 
is related to the lack of self-regulating ability, which results in attacking, denying, distancing, cutting off, and triangling (Titleman, 2014). In this present study, almost all subjects showed excessive emotional reactivity. For instance, they tend to display aggressive behavior when expressing feelings of anger, by hitting or attacking their children/spouse, punching the wall, throwing pieces of stuff, and saying unpleasant words. Furthermore, when feeling sober, they tend to cry for a long time, and they sometimes even faint while crying. One of the subjects also distances themselves by remaining indoors for three months, when saddened. Furthermore, Crandall (2013) stated that another selfregulation inability in emotionally reactive people is in terms of responding to other people's emotional conditions. For instance, in this study, mothers were unable to calm their children when faced with problems and automatically reacted emotionally. They will scold their children first before confirming and seeking information regarding the problem.

In addition, the inability to regulate emotions is not only demonstrated by an excessive emotional response and reactivity but can also be seen from excessive shut down of emotion (Leahy, Tirch, \& Napolitano, 2012). Excessive deactivation of emotion is a condition where someone chooses to suppress his/her emotions so that other people do not know get to know the internal emotions felt (Synder, Heller, Lumian, \& McRae, 2013). This was also found in the current study, where one of the subjects failed to show emotional responses to various negative situations. Even though she felt angry, sad, disappointed, and ashamed, the subject preferred bottling up her emotions. Although she does not show excessive emotional reactions, it does not mean she is better than people who are emotionally reactive. The results of experimental studies show that not expressing negative emotions will not eliminate or reduce those feelings (Egloff, Schmukle, Burns, \& Schwerdtfeger, 2006).

Furthermore, this condition can also lead to the inability to make decisions, and in finding the right solutions, related to childcare. As stated earlier, the absence of emotional expression affects decision making with the inability to determine the right solution to a problem (Heilman, Crisan, Houser, Miclea \& Miu, 2010). Moreover, when the subject faces a predicament, she avoids sharing it with her partner, hence, missing the opportunity to conduct an open discussion. In accordance with the results of Peters, Overall, and Jamieson (2014) study, expressing negative emotion can facilitate social interaction. When we fail to show emotional expression and but rather discuss it with our pals, there will not be a favorable response from partners or spouse, as he or she wouldn't know the gravity of the situation. Socio marital support will be difficult to obtain when the spouse does not know the feelings and emotions felt by the subject. So, these parenting problems cannot be properly resolved.

On the other hand, one subject was capable of managing her emotions according to the situation and conditions. Even though she felt angry and disappointed, she does not act rudely and tried to control herself by staying calm in front of the child. In addition, she was quite capable of managing the shameful feeling, as she was still able to apologize and establish a social relationship with the community and neighborhood. Although she often cried to expresses her sad feelings, especially with regard to her child's case, she was still able to manage her emotion in various situations. This can be as a result of her ability to utilize the values taught by her parents, during her childhood. She applied her parents' parental strategies in regulating emotions and in taking care of her kid/s. As a child, she was emotionally accepted and supported. She also witnessed the way her parents expressed emotions and resolved problems. This was what affected her ability to regulate emotions in the later in life, which in this case was applied when she also became a parent (Moutsiana, Fearon, Murray, Cooper, Goodyer, Johnstone, \& Halligan, 2014). Besides, she also believed that hers was a gift from God. The child's problem made her keep trying to be patient while praying to her God. As stated by Koole, McCullough, Kuhl, and Roelofsma (2010) belief and religious practices have processes similar to selfregulation. They can activate various cognitive procedures, motivational, emotional, and other psychological mechanisms that enhance self-regulation abilities.

Furthermore, the second component of selfdifferentiation is the balance between autonomy and intimacy. Autonomy is related to basic self which consists of "I" position on the subject. The "I" position is an individual's ability to stand for himself, know what his principles are even though they are different from others, and independently express his opinions clearly (Biadsy-Ashkar \& Peleg, 2013). Basic self is a combination of trust, conviction, and ideas that cannot be changed because of social demands (Bowen, 2013). The mothers of the juvenile sexual offenders in this study have a basic self which is more dominant than pseudo self. They are decision makers in the household and a person whose thoughts, beliefs, and ideas are followed by other family members. However, despite having an "I" position, it does not mean they also have a good self-differentiation, because it wasn't balanced with intimacy, with children and other family members.

They tend to make decisions solely based on their personal thoughts and beliefs without considering the condition of the child or other family members. Besides, the bonding between mother and children is not well-established. This was obtained from the mother who did not know about their children's 
psychological condition and their children were also reluctant to tell or share anything about their personal life and problems. Information related to the problems experienced by children is usually received from the school representatives and neighbors. There are only two subjects who are able to show warmth and affection to their children through action and words. Meanwhile, the other subjects are unable to do so. However, this does not mean that the mother does not love their children; it shows the lack of communication in the family. Moreover, the time that they spend together was not enough, due to the mother's job or responsibility outside the home. These things lead to the misunderstanding between mother and children, which the mother feels that they already doing their best for the children but the child might feel that she/he has not obtained the need for affection.

An additional finding in this study is that all mothers are dominant in the family. A father's role in the family is all about earning a living, while the role for decision making, setting rules, disciplining children was that of the mother. Therefore, even though they lacked differentiation of self, they were still in control of the family. On the other hand, the mothers in this study felt they had more severe responsibilities than other family members and felt they did not get support from their husbands while raising their children. However, they continued to carry out their duties even though sometimes they felt really tired and complained about the workload. According to Chesler (2011), there is a double standard which is also a form of stereotypical gender judgment that women are the most important figure in parenting. They are considered to be more nurtured and more involved in carrying out parenting roles. Mothers are required to be able to carry out a series of parenting tasks without any mistakes, while the father tends to have limited parenting responsibilities and if he makes a mistake it is considered normal. This makes mothers often criticized when making mistakes in disciplining children (Villicana, 2015). In fact, if a father can cooperate with the mother in applying the same parenting strategy, this will help the mother to carry out parenting tasks more efficiently (Namaguchi, 2015). In addition, other studies suggest that the lack of participation from fathers is related to increased maternal stress (Nomaguchi \& Brown, 2011).

The results showed that the mothers of juvenile sexual offenders in this study lacked selfdifferentiation. It is also shown from the behavior they demonstrate, such as inability to accept reality, endure stress, and difficulty to think clearly and find solutions to problems. This present study finding is in accordance with Murdock and Gore (Sutherland, Cook, Sterina, \& Hernandez, 2009) study which shows that individuals who lack self-differentiation tend to face difficulties in dealing with stressful events as they are not able to function appropriately. The stressful event in this study is referred to the cases of sexual violence committed by their children along with lawsuits and negative public views. Therefore, differentiation of self is very essential, especially to the mother, in order to deal with those difficult situations and can also be used to improve the effectiveness of children psychotherapy (Hall, 2013).

\section{CONCLUSIONS}

Based on this research, it can be concluded that mothers of juvenile sexual offenders have less selfdifferentiation than their fathers. This is similar to Bowen theory which states that differentiated parents are less able to regulate their emotional responses, maintain a solid sense of self of well-being in relationships, emotionally reactive, and less comfortable with intimacy or autonomy in family relationships. However, each participant had varied dynamic results. Some of the participants can regulate their emotional feelings while others can build intimacy with their children. Besides, some participants can't show their emotional expression either positively or negatively. This is an additional objective that should be considered for further research. Implications from this result are expected be part of treatment therapy for juvenile sexual offenders.

\section{REFERENCES}

Anggreiny, N., Sari, S. M. \& Aziza, A. 2016. Mekanisme Psikologis Remaja Pelaku Kekerasan Seksual. Psikologia: Jurnal Pemikiran \& Penelitian Psikologi, 11(3), pp. 112-122.

Bank Data KPAI. 2016. Sumber: http://bankdata.kpai.go.id/author/kpai yang diakses pada tanggal 30 November 2017.

Birbaum, L. (2005). Adolescent Aggresion and Differentiation of Self: Guided Mindfulness Meditation in the Service of Individuation. The Scientific World JOURNAL, 5, pp.478-489.

Biadsy-Ashksar, A., \& Peleg, O. (2013). The Relationship between Differentiation of Self and Satisfaction with Life amongst Israeli Women : A cross cultural perspective. Health, 5 (9), pp. 1467 -1477.

Brown, A., \& Burton, D. L. (2010). Exploring the Overlap in Male Juvenile Sexual Offending and General Delinquency: Trauma, Alcohol Use, and Masculine Beliefs. Journal of child sexual abuse, 19(4), pp. 450468.

Burton, D. L., \& Meezan, W. (2004). Revisiting recent research on social learning theory as an etiological proposition for sexually abusive male adolescents. Journal of Evidence-Based Social Work, 1(1), pp. 4148 . 
Crandall, A. (2013). The Association of Maternal Emotion and Cognitive Control Capacities to Parenting and Child Well-Being. Ph.D. Johns Hopkins University.

Eliasa, E. I. (2011). Pentingnya Kelekatan Orangtua dalam Internal Working Model untuk pembentukan Karakter Anak (Kajian Berdasarkan Teori Kelekatan dari John Bowlby). Yogyakarta: Inti Media Yogyakarta bekerjasama dengan Pusat Studi Pendidikan Anak Usia Dini Lembaga Penelitian Universitas Negeri Yogyakarta.

Egloff, B., Schmukle, S. C., Burns, L. R. \& Schwerdtfeger, A. (2006). Spontaneous emotion regulation during evaluated speaking tasks: Associations with negative affect, anxiety expression, memory, and physiological responding. Emotion, 6, 356-366

Finkelhor, D., Turner, H., Hamby, S. L., \& Ormrod, R. (2011). Polyvictimization: Children's Exposure to Multiple Types of Violence, Crime, and Abuse. National survey of children's exposure to violence, pp. 1-12.

Franklin, C. A., Bouffard, L. A., \& Pratt, T. C. (2012). Sexual assault on the college campus: Fraternity affiliation, male peer support, and low self-control. Criminal Justice and Behavior, 39(11), pp. 1457-1480.

Friedman, M. S., Marshal, M. P., Guadamuz, T. E., Wei, C., Wong, C. F., Saewyc, E. M., \& Stall, R. (2011). A meta-analysis of disparities in childhood sexual abuse, parental physical abuse, and peer victimization among sexual minority and sexual nonminority individuals. American journal of public health, 101(8), 1481-1494.

Hall, C, M. (2013). From The Bowen Family Theory and Its Uses : The Eight Processes. International Psychotherapy Institute. United State of America.

Heilman, R. M., Crisan, L. G., Houser, D., Miclea, M., \& Miu, A. C. (2010). Emotion regulation and decision making under risk and uncertainty. Emotion, 10(2), 257-265. https://doi.org/10.1037/a0018489

Koole, S. L., McCullough, M. E., Kuhl, J., \& Roelofsma, P. H. M. P. (2009). Why Religion's Burdens Are Light: From Religiosity to Implicit Self-Regulation. Personality and Social Psychology Review, 14(1), 95107.

Kring, A., Johnson, S., Davison, G. and Neale, J. (2014). Abnormal psychology. Hoboken, N.J.: Wiley Custom.

Leahy, R, L., Tirch, D, D., \& Napolitano, L, A. (2012). Why is emotion regulation important?. Psychotherapy in Australia, 19(1), 68-81.

Martin, Earl \& Marsha Kline Pruett. (1998). The juvenile sex offender and the juvenile justice system. The American Criminal Law Review, 35. pp. 279-332.

Margari, F., Lecce, P. A., Craig, F., Lafortezza, E., Lisi, A., Pinto, F., ... \& Margari, L. (2015). Juvenile sex offenders: Personality profile, coping styles and parental care. Psychiatry research, 229(1-2), 82-88.
Marshall, W. L. (2010). The role of attachments, intimacy, and lonliness in the etiology and maintenance of sexual offending. Sexual and Relationship Therapy, 25(1), 73-85.

Moutsiana_C., Fearon, P., Murray ${ }_{L}$ L., Cooper ${ }_{L}$ P., Goodyer $_{\llcorner}$I., Johnstone ${ }_{\llcorner}$T., \& Halligan ${ }_{\llcorner}$S. (2014). Making an effort to feel positive: insecure attachment in infancy predicts the neural underpinnings of emotion regulation in adulthood. Journal of Child Psychology and Psychiatry,55 (9) 999-1008

Nomaguchi, K., Brown, S., \& Leyman, T. M. (2015). Fathers' Participation in Parenting and Maternal Parenting Stress: Variation by Relationship Status. Journal of Family Issues, 38(8). pp. 1132-1156.

Papalia, D.E., Olds, S.W. and Feldman, R.D. (2001) Human Development. 8th Edition, McGraw Hill, Boston.

Peters, B,J., Overall, N, C., Jamieson, J, P.(2014). Physiological and cognitive consequences of suppressing and expressing emotion in dyadic interactions. International Journal of Psychophysiology, 94, 100-107

Prisco, R. (2015). Parental Involvement in Juvenile Sex Offender Treatment: Requiring a Role as Informed Supervisor. Family Court Review, 53(3), pp.487-503.

Suratno. (2014). Pengaruh Lingkungan Keluarga dan Lingkungan Pergaulan terhadap Prestasi Belajar Ekonomi Siswa. Jurnal Pendidikan Ekonomi Dinamika Pendidikan, 10 (1), pp.92-99.

Sutherland, J. A., Cook, L., Stetina, P., \& Hernandez, C. (2009).Women in Substance Abuse Recovery. Western Journal of Nursing Research, 31(7), pp. 905-922.

Snyder, S. A., Heller, S. M., Lumian, D. S., \& McRae, K. (2013). Regulation of positive and negative emotion: effects of sociocultural context. Frontiers in psychology, 4, 259. doi:10.3389/fpsyg.2013.00259

Titelman, P. (2014). Differentiation of Self: Bowen Family Systems Theory Perspectives. washington $\mathrm{dc}$ : routledge.

Villicana, A. J., Garcia, D. M., \& Biernat, M. (2015). Gender and parenting: Effects of parenting failures on evaluations of mothers and fathers. Group Processes \& Intergroup Relations, 20(6), pp. 867-878. 